\title{
THE EFFECT OF THE PHOTOTDYNAMIC THERAPY BY USE OF THE KRYPTONLASER AND META-OH-PARA/CH $3 / 3$-TETRAPHENYLPORPHYRIN ON CELLS OF TRANSPLANTABLE MAMMARY CANCER
}

\author{
P. ZIÓXKKOWSKI, J. MILACH, P. DEREŃ* ${ }^{*}$ and L. LATOS-GRAŻYŃSKI** \\ Department of Pathology, Medical Academy of Wroclaw, 50-368 ul.Marcinkowskiego 1, Poland \\ *Institute of Low Temperature and Structural Research, Polish Academy of Sciences, 50-950 Wroclaw, \\ pLKatedralny 1, Poland \\ ${ }^{* *}$ Institute of Chemistry, University of Wroclaw, 50-383 Wroclaw, ul.Joliot-Curie 14, Poland
}

\begin{abstract}
The results of the photodynamic therapy by use of Erypton-laser and meta-OH-para/CH $/ 3$-tetraphenylporphyrin on cells of transplantable mammary cancer are presented. Irradia-tion time dependent decrease of the number of cells and sup-eroxide dysmutase-activity in experimental group was confir-med.
\end{abstract}

1. Introduction.

Photodynanic therapy/PDT/ is well knowm method of malignant tumo-urs treatment $/ 1,2 /$, in which singlet oxygen, that subsequently impairs cellular organelles, is generated after some physico-chemi-cal reactions $/ 3 /$.

Superoxide dysmutase is supposed to be one of the cellular enzymes, that "neutralizes" free radicels, e.g. singlet oxygen, in intracel-lular space.

In the last few years among many photosensitizers examined, the meso - tetra-hydroxyphenyl- porphyrins/THPP/ showed according to obser-vations of some investigators very promising effect in treatment of tumours $/ 4,5,6 /$.

The meta-OH-para/CH $/ 3$ - tetraphenylporphyrin, TPP, shows very similar structure to one of above mentioned compounds, $i$.e. meta- risP. Therefore we decided to examine the influence of TPP on viable cells of mamary cancer ori ginating from wistar rats.

This photosensitizer has not been yet involved to PDT studies. The waveband selected for use was $647.1 \mathrm{~nm}$ as the well tissue-penetra-ting wavelength adapted to the absorption spectrum of the porphyrin and producing effective cell or tumour damage $/ 7 /$.

2. Naterials and methods.

a. porphyrin /see fig. 1/, meta-OH-para/CH $/ 3$ - tetraphenylporphyrin was prepared at Institute of Chemistry, ${ }^{3}$ University of Wrockaw. The purity of this compound was confirmed by using electronic spectroscopy and proton ragnetic resonance. 


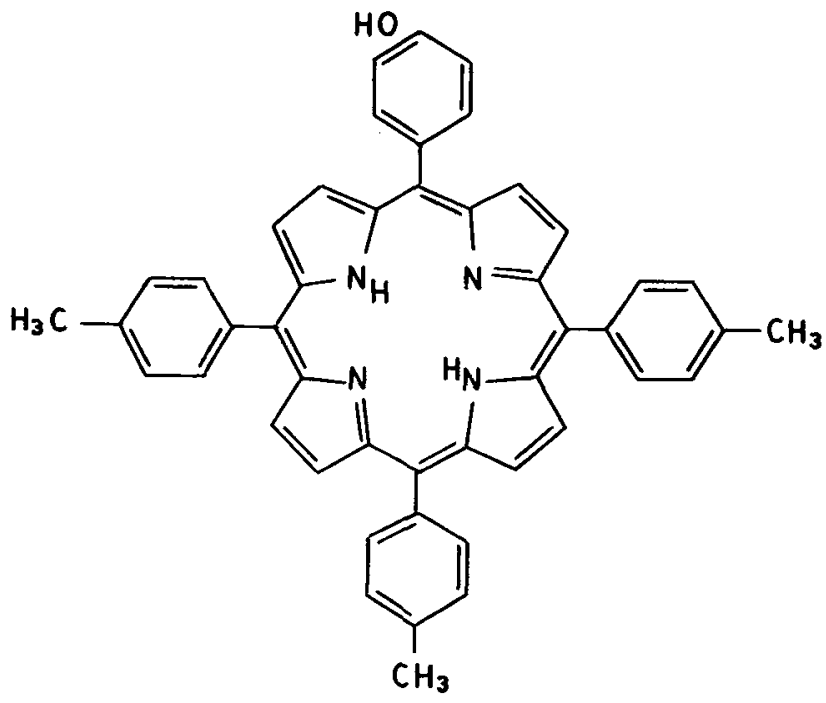

\section{META - $(\mathrm{OH})$ - PARA - $\left(\mathrm{CH}_{3}\right)_{3}-$ TPP}

Fig. 1

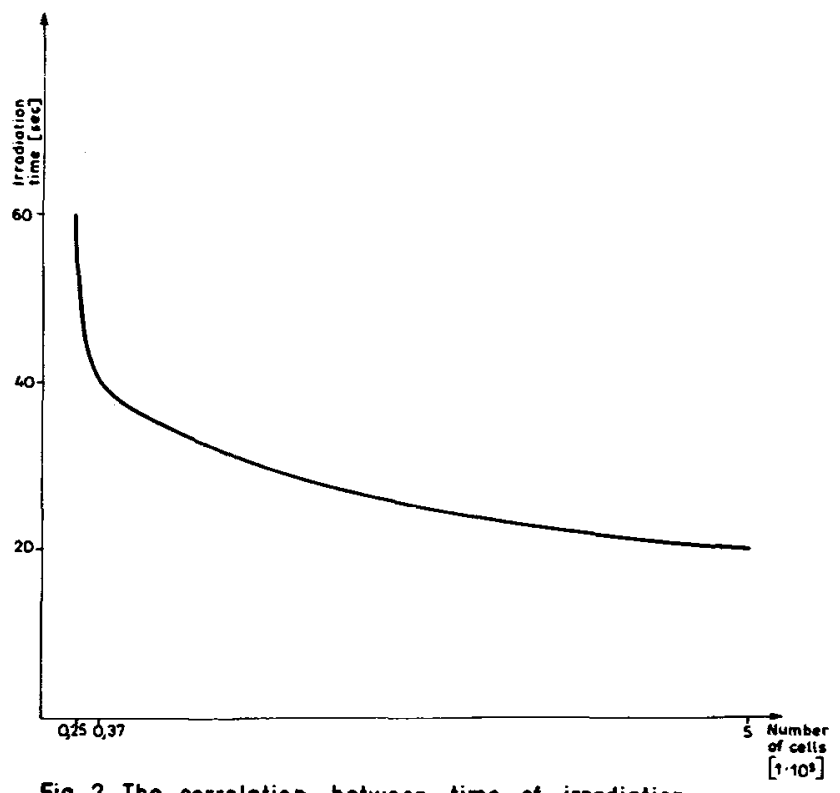

Fig. 2. The correlotion between time of irradiotion and number of cells exposed to therapy 
b. cells, tumour cells derived from passages on Wistar rats were in-cubated in culture medium for 3 hours at $37^{\circ} \mathrm{C}$ with sensitizer. Histologically there were carcinoma solidum mamae cells.

c. Iight source - the illumination of samples was perfomed by a kry -pton-laser IJK 120 /Carl Zeiss Jena, FRG/, the $647.1 \mathrm{~nm}$ line was used. The power of this irradiation was set at $240 \mathrm{~m}$. The diame-ter of the laser beam was about $3 \mathrm{~mm}$.

Tumour cells, in amount of $5 \times 10^{6}$, in sterile conditions were ex-posed to action of $\mathrm{TPP}$ solution, i.e. $1 \mathrm{mg}$ of the sensitizer in 0,5 ml chloroform, and after 3 hours were irradiated with red light for 20,40 , and 60 seconds, it was experimental group.

At the dose $1 \mathrm{mg} / 0,5 \mathrm{mi}$ the cytotoxic effect was minimal and ignored The cells in the same amount were exposed entirely to the action of the sensitizer alone / $1 \mathrm{mg} / 0,5 \mathrm{mI} /$ - the control group I. The cells in the seme amount were left without any further treatment - control group II.

Inally, the same amount of cells were exposed to the action of 1a- Ser alone - control group III.

The activity of superoxide dysmutase /SOD/ was measured according to procedure described by Kurzawski / unpublished data,1991/. The SOD - activities were measured after 20,40 , and 60 seconds of irradiation in all studied,i.e. four, groups.

Results and discussion.

The results of examination are presented on table $1 . /$ see end of text The extension of irradiation time causes the distinct decrease of the cells number in presence of the sensitizer. The most significant decrease was observed in the first 20 seconds. In the next 40 second / i.e. after 40 and 60 seconds of irradiation/ this process seems to be decelerated. In controls we have observed a slight decrease of cells number aiter laser / with no sensitizer / application. The activity of SOD decreased in the greatest extent during the first 20 seconds of irradiation in experimental group. There was sitghter decrease observed in the following 20 and 40 seconds. These results are compatible with the cytotoxic effect of therapy on cells in the same intervals of irradiation. In control groups we have observed only trivial differences independent of irradiation time.

The determination of SOD- activity, one of enzymes delaying singlet oxygon zeneration / Kwiatkowska, personal communication /, may be useful in monitoring the efficecy of the phototherapy. Briefly, the lower ectivities of superoxide dysmutase mean the higher proba-bility of tumour-cell destruction.

The most interesting fact in our study is, that the continuation of irradiation did not cause the rectilineal decrease of the number of cells. This decrease conditioned by red light and porphyrin therapy may be compared with hyperbol / see fig. 2 under the $1 \pm$ gure $1 /$. Probebiy the hundred-per-cent cytotoxic effect,i.e. death of the to-tal cell population, could have been obtained after the very long time of irradiation or after application of high-power density laser equipment. Unfortunately, in the latter the thermal effect may occur 
The mechanisms of the phototoxic effect of porphyrins used in PDT and inactivation of various enzymes are poorly understood $/ 8 /$. Sites of photodanage on cellular level are rather nurierous, e.g. nu-cleus and cell membrane /9/ or mitochondria /10/.

our present results suggesting the possible role of enzymatic alter-ations in mitochonaria or cytosol on the induction of photodamage.

Table 1. Results of the treatment. Irradiation time-dependent decrease of the number of cells and SOD-acitivity in experimental group in comparison with control groups

\begin{tabular}{|c|c|c|c|c|}
\hline $\begin{array}{l}\text { Time } \\
\text { (sec.) }\end{array}$ & $\begin{array}{l}\text { Experimental } \\
\text { (number of } \\
\text { cells) }\end{array}$ & $\begin{array}{l}\text { Control } 1 \\
\text { (number of } \\
\text { cells) }\end{array}$ & $\begin{array}{l}\text { Control } 2 \\
\text { (number of } \\
\text { cells) }\end{array}$ & $\begin{array}{l}\text { Control } 3 \\
\text { (number of } \\
\text { cells) }\end{array}$ \\
\hline 20 & $5.10^{5}$ & $5.10^{6}$ & $5.10^{6}$ & $4,2 \cdot 10^{6}$ \\
\hline 40 & $3,7 \cdot 10^{4}$ & $5.10^{6}$ & $5.10^{6}$ & $4,2 \cdot 10^{6}$ \\
\hline \multirow[t]{2}{*}{60} & $2,5 \cdot 10^{4}$ & $5.10^{6}$ & $5.10^{6}$ & $4,2 \cdot 10^{6}$ \\
\hline & SOU-activity & SOD-activity & SOD-activity & 500-activity \\
\hline 20 & $70 \%$ & $83,5 \%$ & 835 & $83 \%$ \\
\hline 40 & $66 \%$ & $82 \%$ & $81 \%$ & $82 \%$ \\
\hline 60 & $64,5 \%$ & $82 \%$ & $80 \%$ & $82,5 \%$ \\
\hline
\end{tabular}

SOD - superoxide dysmutase 


\section{References:}

1.Bergh H.v.d., Iight and porphyring in cancer therapy, Chemistry in Britain, Hay, 1986, 4.30.

2.Berns H.W., Wile A.G., Hematoporphyrin phototherapy of cencer, Radiotherapy and oncology, 7,1986, 233 .

3.Keene J.P., Kessel D., Land E.J., Redmond R.W., Truscott T.G., Direct detection of singlet oxygen sensitized by hematoporphyrin and rel-ated compounds, Photochem. Photobiol.,43,1986,117.

4.Berenbaum M.C., Akande S.I., Bonnett R., Kaur H., Ioannou S., White R.D Winfield U.J., Meso-tetra/hydroxyphenyl/ porphyrins, a new class of potent tumour photosensitizers with favourable selectivity, Br.J.Cancer, 54,1986,717.

5.Bonnett R., Ioannou S., White R.D.,Winfield U.J., Berenbaum H.C., Neso-tetra/hydroxyphenyl/porphyrins as turour photosensitizers: chemical and photochemical aspects, Photobiochem.Photobiophys. Supp1., 1987,45.

6.Bonnett R.,HoGarvey D.J., Harriman A., Land R.J., Truscott T.G.,Win- fiela U.J., Photophysical properties of meso-tetraphenylporphyrin and some meso-tetra/hydroxyphenyl/ porphyrins, Photochem. Photobiol $48,1988,271$.

7.Gemert J.C.,Berenbaum H.C.,Gijsbers G.H.H., Wavelength and Iightdose dependence in tumour phototherapy with hematoporphyrin deri-vative, Br.J.Cancer, 52,1985, 43.

8. Maziere J.C., Santus R., Horliere P.,Reyftmann J.-F., Candide C., Hora I., SaImon S., Haziere C., Gatt S., Dubertret I., Cellular upta-ke and photosensitizing properties of anticancer porphyrins in cell membranes and Iow and high density lipoproteins, J.Photochem. Photobiol.,B:Biology, 6,1990,61.

9. Santus R., Reyftmann J.-F., Photosensitization of membrane compo-nents, Biochimie, $68,1986,843$.

10. Salet C., Woreno G., Photosensitization of mitochondria.Molecular snd celiular aspects, J.Photochem.Photobiol.,B:Biology, 5,1990,133 